\title{
Quality of life perspectives for different social groups in a World Centre of Tourism and Leisure
}

\section{Jaeyeon Choe}

Huế University, Vietnam

\section{Michael O' Regan ${ }^{(D)}$}

Swansea University, UK

\author{
Albert Kimbu \\ University of Surrey, UK \\ University of Johannesburg, South Africa
}

\section{Niels Frederik Lund}

Erasmus University, Rotterdam

\section{Adele Ladkin}

Bournemouth University, UK

\begin{abstract}
While the quality of life (QoL) concept in tourism research has gained momentum, scholarly work has focused on host $\mathrm{QoL}$ and tourist-host relations, rather than exploring and analysing the perception, interpretation and understanding of $\mathrm{Q} o \mathrm{~L}$ among different social groups in a given tourist destination. Macao is a densely populated tourism destination and designated World Centre of Tourism and Leisure, where local residents and migrants work and cohabit side by side. By broadening the scope of research through in-depth interviews, our research findings highlight how different social groups in Macao experience QoL differently. While all groups perceive positive economic impacts and appreciate career opportunities from tourism development, the analysis raises questions as to the QoL of residents and migrants, and the social sustainability of
\end{abstract}

\section{Corresponding author:}

Michael O' Regan, Swansea University, Singleton Park, Sketty, Swansea SA2 8PP, UK.

Email: Michael.oregan@gmail.com 
Macao. The study recommends that authorities embed a social sustainability focus in deliberations, policies and investment so as to achieve its goal of World Centre of Tourism and Leisure status, not only for tourists, but also for those who live and work there.

\section{Keywords}

Macao, quality of life, social sustainability, sustainable tourism development, World Centre of Tourism and Leisure

\section{Introduction}

Global concerns about overtourism, migrant flows, tourist-host tensions and the COVID19 pandemic are raising questions about the quality of life (QoL) of people and communities in tourism destinations. While tourism research has identified the impact of tourism development on QoL, it also identifies community support as vital to sustainable tourism development (Baros and David, 2007; Choi and Sirakaya, 2006; Eslami et al., 2019; Mathew and Sreejesh, 2017). This research has largely focused on 'locals' or QoL in the limited context of tourist-host relations (Andereck and Nyaupane, 2010; Woo et al., 2015). QoL studies have also adopted a largely quantitative approach and treated residents/host communities as a uniform group (Nunkoo and So, 2016; Woo et al., 2015; Zhou et al., 2015). Research findings show that tourism activities have some positive effect on both tourists' overall life satisfaction and well-being of residents (Uysal et al., 2016). Research is lacking on the consequences and effects of rapid tourism development on different categories of people, communities and populations groups living and working in tourismdependent destinations and the effect on their QoL. Researchers have questioned whether the QoL construct is transferable from one population or social group and context to another, with calls for more research to corroborate individual level findings with studies capturing QoL at the family, community, regional and country level, while articulating pertinent life domains by social groups and settings (see e.g. Uysal et al., 2016).

The current research focuses on Macao, 'Asia's Las Vegas' (Loi and Kim, 2010) and self-labelled as a 'World Centre of Tourism and Leisure' (MGTO, 2017; O'Regan, 2019). While it is a territory of just $33 \mathrm{~km}^{2}$ and a resident population of 658,900 (June 2018), Macao received 39.4 million tourists in 2019. Prior to COVID-19, Macao was expected to become the richest (highest per-capita gross domestic product) territory in the world by 2020 (Carvallo, 2018) due to the rapid development of the tourism industry. This development is primarily driven by the liberalisation of the casino industry in 2002, which accelerated tourism and economic growth. This growth has also led to an increase in imported goods, house prices, traffic, the cost of living and a rapid increase in the migrant workforce. The opening of the Hong Kong-Zhuhai-Macao Bridge, a new runway at nearby Shenzhen airport and the development of Guangzhou - Zhuhai Intercity Railway means the forecast of 40 million visitors by 2025 (MGTO, 2017) is conservative. The increased flows of capital, tourists and workers have created questions about the ability of the local population to cope with ever-increasing tourist numbers, tourism development and impacts on their QoL (Nunkoo and So, 2016; Woo et al., 2015). It also raises questions about governance, political decision-making and the mitigating 
measures taken by authorities and businesses (Hsu and $\mathrm{Gu}, 2010$ ), who have, until very recently, prioritised tourist and economic growth over environmental and social sustainability (Green and Stern, 2014).

With an unemployment rate of just 2.9\% (December, 2020), the number of foreign workers is expected to increase as COVID-19 subsides, as Macao fills positions in the dominant tourism and hospitality industry (Sheng and Gu, 2018), which accounts for an estimated 91.3\% of GDP (Wyman, 2020), According to Macao's Labour Affairs Bureau (2021), the number of migrant workers holding a work visa in December 2020 was 176,000 out of the total labour force of 388,800 . While non-skilled labour is on the rise, the proportion of imported labour that falls under the category of 'professional' (skilled employees) has declined. Without migrant workers, the (gambling) tourism industry would face staffing problems, higher wages and rising costs (GGRASIA, 2014). However, as unskilled migrants cannot look for jobs whilst under a tourist visa, many pay between 2 and 3 months of their salaries to employment agencies as recruitment fees.

Given the lack of comparative studies between different social groups, it is important to consider QoL, from perspectives that include resident workers, but also skilled and unskilled migrant workers (Ladkin, 2011). As there is an anticipated difference between these groups, this study aims to explore how local residents, and skilled and unskilled migrant workers in Macao experience and perceive their QoL, so as to contribute to a comprehensive understanding of QoL in the social sciences by including the perception, interpretation and understanding of QoL by different social groups. By meeting the above aims, this study contributes to existing research in several significant ways. Firstly, nascent research on QoL in tourism research currently neglects an investigation of concepts of QoL among different social groups in tourism destinations. This study adopts a qualitative approach to explore different social group perceptions and interpretations of QoL, including different migrant worker categories. Secondly, as QoL research in tourism research has largely been conducted using quantitative approaches (only 4 of $35 \mathrm{QoL}$ studies reviewed by Uysal et al., 2016 utilised interviews), this study contributes to an in-depth understanding of QoL through a bottom-up qualitative methodology and analysis of in-depth interview data. This method incorporates more diverse perspectives from different social categories of residents that make up the community, and especially those voices that are often neglected, but constitute a significant proportion of the community and the tourism and hospitality labour force. This study can aid Macao Tourism, authorities and the business sector to plan and implement policies and measures to help achieve sustainable tourism development in Macao. The findings can also aid other tourist destinations hoping to achieve destination sustainability.

\section{Literature review}

\section{Definitions and measurements of QoL}

QoL has been used as a conceptual framework in different fields of study and disciplines (Verdugo et al., 2005). Defining QoL is challenging as 'quality' is subjective to cultures, individuals' perceptions and feelings. Given the lack of parametres, there are more than 100 identified definitions and constructs of QoL (Andereck and Nyaupane, 2010; Schalock, 
1997). However, the WHO's QoL group's definition of QoL as the individuals' 'perceptions of their position in life in the context of the culture and value systems in which they live and in relation to their goals, expectations, standards and concerns' (WHOQOL Group, 1994: 1403) has gained increasing acceptance. The definition includes the concern for 'physical health, psychological state, personal beliefs, social relationships and their relationship to salient features of their environment' (WHOQOL Group, 1994). The definition comprises of four dimensions of QoL including material well-being, community wellbeing, emotional well-being and health and safety well-being (Skevington et al., 2004).

Schalock $(1997,2000)$ synthesised QoL concepts into eight dimensions (emotional well-being; interpersonal relations; material well-being; personal development; physical well-being; self-determination; social inclusion and rights). In each dimension, Schalock argues for measuring both objective functional assessments as well as subjective personal appraisals. Cummins (2005) calls for measurement of both objective and subjective components. There is increasing acceptance across social sciences that QoL is a multidimensional concept, which incorporates both objective and subjective components. While researchers accept that the two components should be measured for a comprehensive estimate of QoL (Cummins, 2005; Raphael et al., 1996), the means of measuring QoL remains challenging as there is no definitive scientific design of measuring the construct using objective and subjective domains (Vong, 2005).

Cummins (2005, p. 700) argues that objective components (comprising of culturallyrelevant measures of objective well-being) and its features can be 'observed and measured within the public domain through such properties as physical quantities and frequencies'. These components include economic factors such as employment opportunities, income, job security as well as social factors such as family cohesion, leisure opportunities, cultural integrity, social networks and historical infrastructure. Environmental factors include overcrowding, noise, air or water pollution and traffic congestion (Andereck and Nyaupane, 2010).

Subjective components include personal feelings and perceptions, as it comprises of the satisfaction domain weighted by their importance to the individual (Dissart and Deller, 2000). It incorporates one's 'satisfaction with life and feelings of contentment or fulfilment with one's experience in the world' (Andereck and Nyaupane, 2010: 1). The subjective domain can exist 'only within the private consciousness of each individual and is verified only through repeated responses provided by the person concerned' (Cummins, 2005: 700). The specific subjective dimension encompasses factors such as inner perceptions, experience of happiness, life satisfaction, perceptions of well-being and one's standard of living (Andereck and Nyaupane, 2010). They include the ability to manage feelings, the quality of your relationships and dealing with difficulties, stress and how you feel about yourself. Its impact on QoL and specifically on emotional and psychological well-being can manifest itself in sadness, inability to sleep, losing sex drive and appetite as well as losing interest in life (Rapley, 2003).

The subjective perspectives of how people feel about their lives have led some QoL researchers (e.g. Haas, 1999) to suggest that QoL research should be primarily subjective. However, this study incorporates both subjective and objective domains, with elements that are normatively relevant and culturally important. This creates a bridge 
between objective measures of social situations at a broad population level to the subjective evaluation of individuals, and social groups.

\section{Quality of life and tourism development}

Various studies have indicated the complexity of tourism development. Tourism can result in benefits to residents, due to higher personal living standards through job opportunities. However, rapid tourism development might negatively influence local residents because of perceived overcrowding, traffic bottlenecks, increased cost of living, increased crime rates, conflict between residents and tourists, changes in natural environment and residents' way of life (Nunkoo et al., 2013).

There is a growing interest towards exploring tourism development and QoL from residents' perspectives in broader geographic locations and cultural contexts as QoL has been recognised as an important element for the development of tourism that is not only economically and environmentally responsible but also socially responsible (Mathew and Sreejesh, 2017). Researchers have recognised the importance of QoL and have found positive and negative economic, social, cultural and environmental impacts on residents (Kim et al., 2013; Lin et al., 2013; Terzi et al., 2015; Uysal et al., 2012) and tourists (Uysal et al., 2016). For example, studies in the United States (Andereck and Nyaupane, 2010) and in Shanghai, China (Guo et al., 2014) indicate that residents consider tourism development as having an impact on quantity and quality of outdoor recreational facilities and opportunities, public security, health status, family cohesion, leisure time and living costs.

QoL research has largely focused on economic impacts (Purdue et al., 1999) and economic sustainability (Duncan et al., 2013) such as job creation, which may not necessarily contribute to a positive QoL if such jobs are low paid, seasonal or physically demanding. Economic growth may in some cases lead to deterioration in the social or physical environments (Uysal et al., 2016; Wan and Chan, 2013). More broadly, less attention has been placed on understanding the emotional/psychological and subjective well-being (Choe et al., 2020; Diener, 2000, 2009) off all destination residents, and how particular social groups, such as migrants, are affected by tourism development (Berno and Ward, 2005; Ladkin, 2011). As researchers move beyond economics and measurement of overall community life satisfaction (Andereck and Nyaupane, 2010; Jordan et al., 2015), residents' life satisfaction in specific life domains and perceived value of tourism development are receiving attention (Kim et al., 2013). Recent studies have incorporated residents' perceived value of tourism development in relation to their satisfaction and well-being (Woo et al., 2015) and emotional solidarity towards tourists (Lai et al., 2018). However, studies have largely viewed residents as a monolithic, homogeneous group. They do not acknowledge that in many tourism destinations, there are different social groups, with varying work visas, residency status and other immutable characteristics. There is a need to pay more attention to the 'voices' of various social groups to have a better understanding of their QoL. 


\section{Research methods}

\section{Methods}

While an overwhelming number of existing studies on QoL use a quantitative approach, we adopted a qualitative approach and interpretative paradigm to investigate the subject at an in-depth level, allowing for a more flexible and wide-angle multidisciplinary analysis (Lau and Li, 2019; Souldard et al., 2019). Existing QoL constructs might not be fully applicable to Macao's social, economic, cultural and environmental stage and situation. Consequently, a qualitative research method, which emphasised an open-ended and bottom-up approach was utilised to get to 'the truth of matters, to describe [the] phenomena, in a broadest sense' (Moran, 2000: 4). This enabled us to explore the complexities behind existing QoL constructs, and broader social sustainability factors, and make a methodological contribution to QoL research. Policy makers, community leaders and the business sector need information that demonstrates how a destination is doing not only from a quantitative perspective but also from a qualitative perspective (Morrison Institute for Public Policy, 1997).

We conducted 50 in-depth semi-structured, open-ended anthropological interviews (Bernard, 2012) with local residents $(N=22)$, skilled migrant workers $(N=15)$ and unskilled migrant workers $(N=13)$ between October 2014 and May 2015. The informants were recruited through the researchers' personal and professional networks, using snowball and purposive sampling. The interviews primarily focused on their perceptions and experiences of their QoL in Macao. Questions included all aspects of QoL such as emotional well-being, interpersonal relations, material well-being, personal development; physical well-being, self-determination, social inclusion and rights (Schalock, 1997, 2000) as well as community well-being (Skevington et al., 2004).

By conducting qualitative interviews, we attempted to 'discover the meanings that participants attach to their behaviour, how they interpret situations, and what their perspectives are on particular issues' (Woods, 2006: 2), as well as acquiring a better understanding of processes within the society, cultural group or community in which they belong. As two of the authors were skilled migrant workers living in Macao during the data collection period interviews were combined with ethnographic observation. Their first-hand experience of interacting with various social groups was valuable to the research design, as it indicated that social groups in Macao be seen, not as different 'ethnic groups'; but groups based on other immutable characteristics, such as residency rights and visa category. These categories ensure groups are sufficiently distinct, and are recognised in Macao as discrete classes of persons with particular occupations, lifestyles, leisure behaviour, etc. Identification of these categories allowed the authors to go beyond description and explore emerging patterns by enabling an in-depth explication of the phenomenon under investigation (Matthews and Ross, 2010). While this creates a potential for expectancy effects, the data collection, triangulation and coding process ensured the quality, trustworthiness and rich rigour of the data collection, analysis processes and writing up (Decrop, 2004; Tracy, 2010). 


\section{Data collection and analysis}

Using snowball and purposive sampling (Bernard, 2012), only informants over 18 years old and employed in tourism, hospitality and related occupations were selected. Residents, identified as born and living in Macao and holding Macao residency were working at various casino hotel departments, as employees and in managerial roles. Skilled migrant workers worked primarily at managerial level, since they were employed under a skilled immigration contract. They must possess certain qualifications technical skillsets, or relevant and extensive professional experience in the field. They are therefore, by and large, occupied in high paying positions, as their employer has to show that they are not able to hire a suitably qualified person locally for the advertised position. Unskilled workers are hired by certain employers of good standing, who are given a particular quota, on the basis they also hire locals. While the local-foreign quota ratio is not published, unskilled workers largely work for hospitality business and casino hotels, who are recognised as having the ability to recruit a high proportion of unskilled workers. Unlike skilled migrants, who are hired directly by employers, unskilled migrants have to pay employment agencies as recruitment fees before gaining a visa. The unskilled migrant workers interviewed in this study happened to be primarily from Southeast Asia, such as Indonesia and the Philippines, given the geographic proximity and employer preference for staff from those countries.

The lead author hired and trained two final year tourism and hotel management students to conduct interviews with residents in Cantonese. The interviews were then translated into English, checked and confirmed via a reverse-translation. The interviews with skilled migrant workers were conducted in English by the authors, as they spoke English or were from English-speaking countries. The migrant workers were also interviewed by a student research assistant. The in-depth anthropological interviews lasted between 40 and 60 minutes, and were conducted in quiet places including coffee shops, university offices and informant houses. The combination of residents, skilled and unskilled resident migrant workers ensured that 'a broad cross-section of views and opinions [were] canvassed on the topic of interest' (Kimbu and Ngoasong, 2016: 70). To gather more in-depth data, informants were encouraged to speak about their life stories that are related to their QoL in Macao. All interviews were digitally recorded with the informants' permission.

An in-depth thematic analysis of the interview transcripts and notes in relation to the research aims enabled the identification and creation of primary categories and key themes. The data inside the themes were meaningfully related to each other, and there was enough supportive data to conclude that the themes 'work' in relation to the data set (Ryan and Bernard, 2003). The authors sought out any additional data within themes that has been missed in earlier coding stages, so as to further refine the themes, and identify the 'essence' of what each theme is about (Creswell, 1998). They then critically selected important direct quotes, which were used to support the empirical analysis.

There was general consensus among the authors that public transportation and overcrowding, the economy, job satisfaction and sense of community were key themes. The selective and interpretive nature of the interviews means that every attempt has been made to reveal a balanced assessment of the collected data (Ngoasong and Kimbu, 2016). 
The empirical analysis is presented in the next section with local residents coded as LR, skilled migrants as SM and unskilled migrants as UM. Additionally, by ensuring data checking, validity and reliability, our methods and findings could be applicable to other similar tourism destinations (Bernard, 2012; Decrop, 2004).

To achieve trustworthiness, all five authors discussed the data, relevant meanings and possible conceptualisations at length. Our interpretative analytic style involved immersion and crystallisation, to allow for 'a more complex, in-depth, but still thoroughly partial, understanding of the issue' (Tracy, 2010: 844). As knowledge is situated, partial, constructed; multiple viewpoints are acknowledged (McWha et al., 2018), we rely on our grasp of the phenomenon and context to offer a deep and complex interpretation (Ellington, 2009). We acknowledge the methodological limitation that the informants might not represent all Macao residents and skilled and unskilled migrant workers. Because some of the anthropological interviews took place with informants from nonEnglish speaking cultures, our reliance on research assistants was a limitation, given the assistants might be perceived by informants as having a lower status or skillset for conducting interviews. As this paper is based on was a snapshot study in a territory in continual transition and development, a longitudinal QoL research project could incorporate multiple perspectives and measure changes in QoL of those not in full-time employment, or those whose not impacted by the tourism industry. Finally, from a phenomenological perspective, QoL is inherently individual. While accounts that departed from the dominant story in the analysis were not ignored during coding, more nuanced contrasts within social groups could be represented in a further study, with greater levels of specificity on each social group, given differences of experiences and understanding can occur within social groups.

\section{Findings}

The four key QoL related themes that emerged from the data included both objective and subjective QoL indicators and result primarily from the authorities' heavy focus on gaming and casino development (macro-economic sustainability) over residents and migrant workers' QoL.

\section{Job satisfaction}

Local residents did not indicate feelings of job satisfaction. This was primarily related to their poor work-and-life balance and interrupted family life due to shift work at casinos. All informants considered their jobs just as a means of making money, with low perceived benefits. Some felt mistreated at work and could neither report nor resolve issues, such as career progression. Family members living together resorted to communicating with each other through an app called 'WeChat' due to the work schedules and work-life challenge in a 24-7-365 'at any time, all year round' casino based economy. Family QoL deteriorated even though all members are employed. This was strongly expressed in quotes: 
I have no feeling toward my job but just look as the money. . .I start working at mid-night and finish at eight in the morning. But suddenly, I work from eight in the morning and finish in the evening. So my working schedule is completely unstable and changing all the time. It is terrible. . .I am always tired, and when I come home from my shift, I don't want to do anything (Local Resident).

My shift starts at 20:00 and when I leave home, there is no one. Then I come back home at 04:00 they are all asleep. Most of the communication [with family] is through 'WeChat' and less and less face to face unless we actively plan a dinner and get a day off on the same day and see each other. . . it is really difficult to schedule a day-off on the same day! Sometimes there is no way we see each other for an entire week! In the past [before the casinos], we lived like a normal family. . . (Local Resident).

Skilled migrant workers on the other hand expressed satisfaction with their jobs as they usually get better jobs with higher salaries in Macao than in their home countries. They were especially satisfied with their salary levels and career progression opportunities.

It has been a lot harder to find work in the US over the past few years. And the actual work, with the major companies that are here now, are of international standards. It is just like working in Las Vegas or Hong Kong or Singapore you can find equivalent level of positions here (Skilled Migrant).

I am totally satisfied with my job, I love the work atmosphere. I work together with a mix of cultures (Taiwan, Portugal, America, etc.), which makes everything really interesting and you can see things from different perspectives. We work along pretty well, and do things besides work, like going out for lunch, bowling (Skilled Migrant).

The unskilled migrant workers, many with low incomes, were somewhat satisfied with their jobs. Many of them noted that they were 'lucky' to have a job with salary levels much higher than back in their home countries, to financially support their families overseas. They were proud that they could offer their families and children opportunities such as education and house purchase deposits. However, many of them believed that long working hours and lack of holiday entitlements were challenging.

I have many jobs, but I am satisfied. Firstly, my stage job is satisfying because I get to meet many different people every week. . . I can maximize my communication and social skills. . . my retail job is where I can relax a little bit more. My singing job is my passion, it is not only about the money but it's about doing something that I really love and something that I am really good at (Unskilled Migrant).

I am not satisfied, because of long working hours; the schedule is very complicated. When someone goes on a vacation there is no day off just for us to cover him or her. The job itself is really tiring . . . I can handle it although I am almost giving up (Unskilled Migrant).

Similar to skilled migrants' experiences, unskilled migrant workers did recognise the positive objective QoL indicators such as job opportunities and higher salaries as compared to their home countries. Nevertheless, they bemoaned the lack of career progression opportunities. While they had largely negotiated acceptance in the workplace, they 
understood that discrimination interacted with structural constraints to limit progression from low-paid work. They were also unhappy with their family life due to work schedules and being geographically distant from their families. They looked at their jobs as a means to save and remit money instead of fulfiling self-development opportunities.

\section{Overcrowding and public transportation}

The second theme identified relates to public transportation and overcrowding. There were serious transportation issues in Macao due to poor investment in transport infrastructure (Wan and Li, 2013). The findings of a 2015 government sponsored study by the Institute for Tourism Studies (2015) suggest that residents have grown weary of the effects of continuous tourism growth and perceived overcrowding is impacting QoL. Congestion on sidewalks, streets and vehicle traffic on roads creates restrictions and inconvenience. This was strongly expressed by both local residents and skilled migrant workers alike.

This is directly what the casino development and economic boom brought to us. Overcrowding is a very serious problem in Macao. No matter whether weekdays or weekends, if you want to go to some places near tourist attractions, you will find that you can't move because it is too crowded. (Local Resident)

The buses are congested and go slow. There are 1000 taxis in the city. . At any one day there are over 100,000 tourists here. . . the taxis are too few and the buses are full. Your only solution is to walk or go by car but there is nowhere to park. . . It is really bad. . the government doesn't seem to notice that all the streets are full. (Skilled Migrant)

Some informants noted that on weekends, they would rather stay at home and not travel anywhere because of poor transport options. Others felt taxis were not an option as taxi drivers preferred to take tourists to casinos where they could get return passengers than take people to and from residential areas. These results are consistent with existing studies showing that tourism development can negatively influence local residents because of overcrowding and traffic bottlenecks (e.g. McCool and Martin, 1994). However, unskilled migrants did not express strong views about transportation issues, with many mentioning Macao's transportation as being better than their home towns and cities in Southeast Asia. Some informants commented that they could still visit friends and relatives within Macao by public transport, which was considered convenient.

\section{The economy, housing issues and affordability}

All the informants were worried about their place in a rapidly changing economy due to the systemic risk of over-dependence on gambling. House prices and other living costs were rapidly increasing due to casino developments at the same time of increasing housing demand by young people and non-resident workers. Salary levels were not rising to cover these increased living costs. 
Young people can never afford to buy a house since the prices are too high. This is the impact of Macao's booming economy. . The increase in the cost of buying a house is 10 times compared to 10 years ago but the salary has only doubled. Therefore, buying an apartment or a house is not an option anymore. (Local Resident).

Similar to Schalkwyk et al. (2006)'s study, younger people in Macao felt unable to plan their financial future, with married couples often deciding to continue living with their parents because of high living costs. Residents and migrants in this study felt there was a little hope of resolving the housing issues and living costs due to the focus on gaming and casino development. Despite been lured by rapid economic growth and employment opportunities, skilled migrants with higher incomes expressed more dissatisfaction with their housing options and quality than low income unskilled migrants. Skilled migrants compared their housing conditions with their previous living conditions prior to Macao. As Macao has one of the highest population densities in the world, they were unhappy with smaller living spaces, noise population and limited spaces for relaxation and family activities.

My concern is that the rent keeps going up and a huge part of my salary goes to housing. I wonder whether I am able to afford the rent if I remain in the current situation. Presently I share my house with two and sometimes three other people. . How do you have good quality of life after paying? (Skilled Migrant)

Housing is hard. . .There are so many things to pay, so much deposit; sometimes it will get you thinking if they're cheating us! It's unfair, because some residents have the housing subsidy or a government house. (Unskilled Migrant)

Interestingly, unskilled migrants were also dissatisfied with the housing situation due to the high rental costs, low housing allowances from employers, which often forced them to share rooms with other unskilled workers. However, compared to skilled migrants, they did not express their worry excessively about the room sizes and conditions. Those with a better financial foundation did not necessarily have higher life satisfaction than those who did less well financially.

\section{Lack of a sense of community}

The fourth theme that emerged from migrants (but not locals) interviews is related to the sense of community. Skilled migrants believed it was difficult to make friends because there were no places or events to meet people. Too many migrants left Macao after a short time due to low QoL. They noted that it was very difficult to communicate with local people because of the language barriers and the cultural differences (Janta et al., 2012).

Local people do their own thing and they don't talk much. . .Their social life is eating out, but my perception about socializing is maybe having BBQ or going to karaoke, drinking and chatting together. . .I don't have many friends, mainly foreigners. . .when I go out, I mainly socialise with foreigners. (Skilled Migrant) 
. . Another problem why I cannot socialize here, apart from culture [is that] we have different interests. . .It is not about language, we really look at the world from different perspectives. (Skilled Migrant)

Unskilled migrants felt more discrimination and a lack of acceptance in Macao. They indicated that there was no place like home, and if they had a choice, they would relocate back to their home countries. They were dissatisfied with their long working hours and limited affordable leisure facilities, spaces and options. While there was a broad belief amongst unskilled migrants that they couldn't find a sense of community, various identity markers, such as race, exacerbated their personal experiences and exposed their intersectional identity. Those informants who sought to negotiate their intersectional identity by learning Cantonese, perceived the effort as having little impact on their sense of community.

Community to me is better in the Philippines. People are actually concerned about you, they are helpful, and thoughtful unlike here they don't really care since I am a different race to even start with. (Unskilled Migrant)

I don't feel like there is a sense of community in Macao. . . people here are judgmental, biased and unfair, even though you have Macao ID, you were born and grew up here, they don't really consider you as part of Macao community and they discriminate you (because of your ethnicity). (Unskilled Migrant)

While skilled and unskilled migrants describe 'sense of community' differently, both emphasised that the sense of community was an important indicator for their QoL and emotional well-being. They were dissatisfied with a lack of a sense of community and communication. The sense of isolation was more profound amongst unskilled migrants due to living apart from their families and social discrimination. Their salaries were unable to support a spouse to move to Macao, as they would not be legally able to work. Children would not be allowed to access public services, such as public schools. They felt a lack of social support and voice (Paillard-Borg and Hallberg, 2018). Compared to locals and skilled migrants who enjoy the same leisure activities, ambience and amenities that attract tourists (Williams and Hall, 2000), unskilled migrants have fewer opportunities to develop strong community connections (Liu et al., 2017) and their ethnicity/race has been identified as a constraint to forging community connections (Spracklen et al., 2015). We have learned that despite being tourism dependent, and heavily reliant of migrant labour to service the industry, the authorities do not have a strategy for supporting and integrating migrants into the community. Authorities don't offer enough language support, tourismspecific training programmes or inclusive community spaces or events to bring together social groups (De Haan et al., 2013). Migrant labour is seen as temporary, and quite disposable.

\section{Discussion}

QoL has been recognised as being impacted by tourism, but is also recognised as an important element for the development of tourism. Whilst QoL research in tourism studies has gained momentum, existing research often neglects to consider broader social 
groups and how QoL coalesces and diverges across different social groups such as migrant populations (Berno and Ward, 2005; Ladkin, 2011) in tourism destinations. Thus, this study makes a unique contribution to tourism studies by incorporating different social groups' experiences and perceptions on QoL. This study also explored tourism development and QoL from multiple perspectives in a non-Western context (Choe et al., 2020). This study contributes broadly to social sciences research by utilising a bottom-up qualitative approach to investigate QoL at an in-depth level (Bernard, 2012). This approach incorporated perspectives from different social categories and revealed the importance of researching the perceived QoL of different social groups (Babar et al., 2018; Buch et al.,2014; Duncan et al., 2013).

While this study identified the dominant themes that determine QoL, our findings highlight that the three social groups have a diversity of experience, leading to variations within the groups as to their perceptions of specific QoL factors. Informants in all three groups perceived level of satisfaction with employment opportunities differently. As identified in other empirical studies (e.g. Nunkoo et al., 2013; Yew, 2007), local residents saw their job as a means of making money. However, they expressed low job satisfaction because of a lack of social welfare, and interrupted family life due to shift work at casinos. While skilled migrants expressed satisfaction with their salary levels and career development opportunities, unskilled migrants felt lucky just to have a job, so as to financially support their families back home. The job opportunities in Macao were perceived positively as an objective QoL indicator (Cummins, 2005), with a low unemployment rate of $1.9 \%$ (February, 2020). However, unskilled migrants were unhappy with a lack of career progression opportunities, job insecurity, long working hours, holiday entitlements and a visa policy that does not support their families moving to Macao. While authorities have reduced migrant visa quotas, the 'use and discard' (Yeoh, 2006: 36) strategy regulates unskilled migrants in particular. Negative perceptions towards career progression and work - life balance (a subjective indicator) were based on residents and unskilled migrants' own experiences.

Given the number of tourists in Macao, there are residents' perceptions of overcrowding, combined with perceptions of poor public transportation and housing. Skilled migrants, many of whom had higher expectations of QoL expressed dissatisfaction with aspects of their living conditions, including the limited housing options/quality but also the lack of green spaces. However, unskilled migrants did not express strong views about these issues and perceived Macao's transportation system as better than their home towns and cities. As QoL depends on individuals' previous experiences, expectations and concerns, the living conditions and environment in Macao were perceived differently by social groups.

We also found that community engagement and sustainable livelihoods were important for informants, with all social groups striving for a balanced QoL. While this is similar to findings in previous research (e.g. Matthew and Sreejesh, 2017; Skevington et al., 2004), our study found both migrant groups felt culturally and socially excluded. They experienced poor community and social connection, and found it difficult to develop strong ties or networks. However, skilled and unskilled migrants described their experiences of 'sense of community' differently. Skilled migrants fared better socially than unskilled migrants due to their nationality (mainly from the West), financial security and 
their subjective perceptions of social status provided by their occupation. The unskilled migrants who were primarily from developing Southeast Asian countries experienced exclusion, tinged with social discrimination (Shi, 2017), given their ethnicity/race was a constraint. They perceived social inequality (Lin et al., 2015), and felt limited social support. Discrimination and inequality suffered by migrants is a subjective component of their QoL (e.g. Andereck and Nyaupane, 2010; Choe et al., 2020; Dissart and Deller, 2000), and specifically relates to their emotional/psychological and subjective well-being.

Interestingly, our informants' perceptions about tourism development were different from previous research. Guo et al. (2014) found that residents in Shanghai had positive perceptions of tourism impacts, and recognised tourism development's positive influence on their QoL. Andereck and Nyaupane (2010) also found residents in Arizona perceived tourism as having a positive influence on their QoL in regard improved recreation amenities, feelings of community pride, preservation of natural and cultural resources and community well-being. While the decision to develop gambling was driven both by economic imperatives and political exigencies that developed under colonial rule (O'Regan, 2019), poor perceptions of the tourism sector in Macao are a result of the dominance of casino resorts on the whole economy, the reliance on millions of mainland tourists and the inability of authorities to diversity the economy in any meaningful way.

Despite economic prosperity, there are no clear regulatory mechanisms for residents and migrant voices to be heard (O'Regan, 2019), with authorities largely focused on economic policy interventions such as income assistance, subsidies, cash handouts and employment quotas for residents (Woo et al., 2015). While one's QoL in a tourist destination like Macao is partially a reflection of its contribution to one's standard of living and socio-economic status, it is also a reflection of its contribution to one's social development and environment. Whilst local people have benefited economically through salaries, work quotas and access to housing, less educated residents and migrant workers often benefit less because other economic opportunities aren't available to them (Cheng and Wong, 2007). Migrant workers' rights groups also have little voice in Macao (Moura, 2019), and as a consequence, are paid from $20 \%$ to $35 \%$ less than local workers for comparable jobs (Sim and Wee, 2009). The lack of any trade union law, which was rejected for the 10th time in 2020, or legal protections for migrant workers is damaging to their subjective perceptions regarding job security. During the COVID-19 lockdowns, only residents, for example, were entitled to government subsidies like consumption vouchers. Many migrant workers from overseas countries are effectively prohibited from leaving, as they cannot re-enter Macao. The Labour Affairs Bureau (DSAL) indicates the number of non-resident workers fell 18,875 between December 2019 and December 2020. Given Law No. 10/2020 states that non-residents seeking employment in Macao need to secure a work permit before entering, unskilled migrants who lose their jobs or had had their permits expire, face unemployment, poverty and repatriation. While resident discontent is prioritised, a sense of unfairness amongst other groups may impact socio-political relationships and undermine any improvement in well-being (Tong and Yuen, 2008).

Importantly, we found that objective and subjective indicators are intertwined in informants QoL experiences and perceptions. While objective features can be measured 
Table I. Informants' objective and subjective QoL experiences.

\begin{tabular}{|c|c|c|}
\hline & $\begin{array}{l}\text { Objective indicators } \\
\text { (Andereck and Nyaupane, } \\
\text { 20I0; Cummins, 2005; Raphael } \\
\text { et al., 1996; Vong, 2005) }\end{array}$ & $\begin{array}{l}\text { Subjective indicators (Andereck and } \\
\text { Nyaupane, 2010; Cummins, 2005; Dissart } \\
\text { and Deller, 2000; Haas, I999; Raphael } \\
\text { et al., 1996; Rapley, 2003; Vong, 2005) }\end{array}$ \\
\hline \multirow[t]{2}{*}{ Local residents } & Increased job opportunities & Low job satisfaction \\
\hline & $\begin{array}{l}\text { Poor public transportation and } \\
\text { housing issues }\end{array}$ & Feelings of 'broken' family relationships \\
\hline \multirow[t]{2}{*}{ Skilled migrants } & Increased job opportunities & High job satisfaction \\
\hline & $\begin{array}{l}\text { Overcrowding, poor public } \\
\text { transportation and housing } \\
\text { issues }\end{array}$ & $\begin{array}{l}\text { A lack of a sense of community } \\
\text { Poor living conditions }\end{array}$ \\
\hline \multirow[t]{5}{*}{ Unskilled migrants } & $\begin{array}{l}\text { Increased job opportunities } \\
\text { A lack of pathways for them to } \\
\text { gain secure employment }\end{array}$ & $\begin{array}{l}\text { A lack of community connection, social } \\
\text { networks and connections }\end{array}$ \\
\hline & Difficult to gain any type & Feelings of social discrimination \\
\hline & of permanent residency & Feelings of social inequality \\
\hline & arrangement for them or & Limited social support and loneliness \\
\hline & family members & Low satisfaction with career progression \\
\hline
\end{tabular}

within the public domain through physical quantities and frequencies (Cummins, 2005), there are difficult measurement challenges to gauge subjective perceptions of QoL, given individuals may understand or respond differently to very subjective facets of life such as stress, inner perceptions, experience of happiness, life satisfaction and perceptions of well-being and one's standard of living (Andereck and Nyaupane, 2010), as well as losing interest in life (Rapley, 2003). The findings also draw attention of the importance of selecting an appropriate assessment techniques, which incorporate the QoL of social groups (Table 1), and their particular perceptions, irrespective of their nationality, culture and even legal status. However, we conclude that subjective QoL among different social groups are equally important as objective indicators. We also argue that both should be emphasised in government measurement, in order to create pathways towards sustainable tourism destination development.

While the tourism workforce is no longer a marginal topic in sustainable tourism research (Baum, 2018; Knollenberg et al., 2019; Ladkin, 2011; Robinson et al., 2018), existing research focuses on either the perspective of the employer (Baum et al., 2016) or that of expatriates and lifestyle migrants (Babar et al., 2018; Benson and O'Reilly, 2009; Buch et al., 2014). Though the importance of attracting and retaining migrants has been noted by researchers (Duncan et al., 2013), little attention has focused on unskilled migrants and other groups such as asylum seekers and undocumented migrant workers. Our study makes a meaningful contribution to the tourism study by bringing in often marginalised voices, and emphasises that social perspectives deserve more attention in QoL research. Indeed, tourism development should not be about 'providing low-level jobs to a disempowered labour force' (Scheyvens, 2011: 162). The importance of well-being, liveability, equity and community engagement remain largely unaddressed in tourism studies, 
and are important issues to address. The QoL of all individuals and communities may help achieve socially sustainable tourism development (Aspinall et al., 2011).

\section{Quality of life and social sustainability}

While sustainable tourism development consists of economic, social and environmental components (Dangi and Jamal, 2016), we argue that social dimensions needs more attention in QoL research (Scheyvens, 2011; Zhang et al, 2017), given economic and environmentally sustainable development too often remain the core focus (Zhang et al., 2017). The QoL concept is increasingly recognised as a key component of social sustainability and the collective functioning of society, not only in terms of individual QoL, but also delivery of cleaner, safer, healthier, successful and well connected communities and societies. The concept offers a framework to deliver a better QoL for all those in a destination in the longer term (Perlaviciute and Steg, 2018) and can be defined as 'development (and/or growth) that is compatible with harmonious evolution of civil society, fostering an environment conducive to the compatible cohabitation of culturally and socially diverse groups while at the same time encouraging social integration, with improvements in the QoL for all segments of the population' (Polese and Stren, 2000: 15-16). Social sustainability seeks to enhance the protection of all people regardless of colour, origin, culture or socio-economic status by fostering the adaptation of just and equitable social, economic and environmental policies that promote a sense of community, integration, safety, health and place attachment (Eizenberg and Jabareen, 2017). As the principles of equity, health and justice are central components of social sustainability, key indicators of social sustainability include education, local democracy, labour standards, social inclusion and order; social capital, safety, fair distribution of income, tolerant attitudes, community cohesion, health, workplace health and safety (Dempsey et al., 2011; Fainstein, 2010). It also includes decent housing conditions, sustainable transport, sustainable urban design, greening and accessibility (c.f. Dempsey et al, 2011; Eizenberg and Jabareen, 2017; Jabareen, 2006). In the workplace, it involves promoting equal opportunities for all genders, maintaining fair levels of pay, embracing diversity and placing close attention to the impact of the businesses operations on all social groups. Social sustainability, therefore, aims to improve the QoL at all levels.

Whilst Jabareen (2006) stresses diversity as the constitutive process of ensuring social sustainability, Dempsey et al. (2011) note that the sense of place attachment, community stability and social belonging are key to ensuring social sustainability. The lack of social infrastructure, support for community development and respect for equality and social justice means QoL, if interpreted differently by different social groups, can cause tensions between social groups.

\section{Conclusion}

Destinations cannot be seen as a successful without understanding the voices of different social groups, and their perceived QoL. An enhanced QoL can attract and retain migrants and local residents in tourism-dependent communities as well as improve the sustainability of the tourism industry, given residents and migrants are critical to tourism destination 
development and directly affect the tourist experience. Government should focus on creating liveable communities for both local residents and migrant workers, as both are crucial for sustainable tourism development (Devine et al., 2007; Joppe, 2012; McDowell et al., 2009). Governments and businesses need to approach QoL through a broader social sustainability perspective that involves listening to social groups, about the importance of particular sustainability indicators, if they hope to achieve destination sustainability.

Sustainable tourism development should incorporate social sustainability (Saarinen and Rogerson, 2014) as a framework to bring together and measure a wide range of factors that influence QoL and identify how individual and collective enhancement can be achieved. Authorities should acknowledge that migrants contribute to cultural diversity and allow informal groups or associations that represent different social groups to make their views heard. Social sustainability can be achieved by forming new inclusive networks such as community advisory boards or planning forums with representation from all community groups, so as to specifically focus on mitigating potential tourism development impacts on communities (Aspinall et al., 2011). At a time when the importance of social sustainability in cities and tourist destinations (Dun, 2014; Stephenson and Ali-Knight, 2010), authorities (as well as investors and business) that invest in social sustainability, through the development of processes and structures that protect and enhance, the interests, well-being and QoL of all people and communities at all levels may gain a competitive advantage.

Further research should be conducted with larger and broader informant circles and include focus groups to provide richer data. Further analysis could then be conducted to explore whether perceptions regarding perceived value of tourism development might be different depending on the social group, personality, demographic character and occupation and any variances with a same social group. It would be fruitful to conduct longitudinal studies where data could be generated at different points in time. This would help us understand the impact of disruption events like COVID-19 on QoL and whether economic indicators take precedence in both the short-to-long term. A combination of quantitative and qualitative data to enhance the richness of data may enrich our understanding of QoL and social sustainability and thereby improve the applicability of findings to other destinations. Further research on the relationship between QoL and social sustainability in other rapidly growing tourism destinations can contribute to the growing literature on sustainable tourism development. Tourism research in general needs to address the voices of minority groups, who are often differentially influenced by tourism development within a community (Andereck et al., 2007).

\section{Funding}

The authors disclosed receipt of the following financial support for the research, authorship, and/ or publication of this article: We received a research fund from the Institute for Tourism Studies (IFT), Macao.

\section{ORCID iD}

Michael O’ Regan (D) https://orcid.org/0000-0001-8177-2739 


\section{References}

Andereck, K. L. and G. P. Nyaupane (2010) 'Exploring the Nature of Tourism and Quality of Life Perceptions Among Residents', Journal of Travel Research 50(3): 248-60.

Andereck, K. L., K. Valentine, C. Vogt, et al. (2007) 'A Cross-Cultural Analysis of Tourism and Quality of Life Perceptions', Journal of Sustainable Tourism 15(5): 483-500.

Aspinall, A., J. Cukier and B. Doberstein (2011) 'Quality of Life and Social Sustainability: Ski Tourism Development in Invermere, British Columbia', Journal of Environmental Assessment Policy and Management 13(2): 179-201.

Babar, Z., M. Ewers and N. Khattab (2018) 'Im/Mobile Highly Skilled Migrants in Qatar', Journal of Ethnic and Migration Studies 45(9): 1553-1570.

Baros, Z. and L. D. David (2007) 'Environmentalism and Sustainable Development From the Point of View of Tourism', Tourismos: An International Multidisciplinary Journal of Tourism 2(2): 141-52.

Baum, T. (2018) 'Sustainable Human Resource Management as a Driver in Tourism Policy and Planning: A Serious Sin of Omission?' Journal of Sustainable Tourism 26(6): 1-17.

Baum, T., A. Kralj, R. N. S. Robinson, et al. (2016) 'Tourism Workforce Research: A Review, Taxonomy and Agenda', Annals of Tourism Research 60: 1-22.

Benson, M. and K. O'Reilly (2009) 'Migration and the Search for a Better Way of Life: A Critical Exploration of Lifestyle Migration', The Sociological Review 57(4): 608-25.

Bernard, H. R. (2012) Social Research Methods: Qualitative and Quantitative Approaches, 2nd edn. Thousand Oaks, CA: SAGE.

Berno, T. and C. Ward (2005) 'Innocence Abroad: A Pocket Guide to Psychological Research on Tourism', American Psychologist 60(6): 593-600.

Buch, T., S. Hamann, A. Niebuhr, et al. (2014) 'What Makes Cities Attractive? The Determinants of Urban Labour Migration in Germany', Urban Studies 51(9): 1960-78.

Cheng, V. and S. L. Wong (2007) 'Problem of Poverty', pp. 247-70, in S. L. Wong, Y. M. Yeung, P. S. Wan, et al. (eds) The Quality of Life in Macau. Hong Kong: Hong Kong Institute of Asia-Pacific Studies Chinese University of Hong Kong. [in Chinese].

Choe, J., O'Regan, M. and A. N Kimbu (2020) 'Filipino Migrant Workers' Leisure and Subjective Quality of Life in Macao', World Leisure Journal 62(3): 242-60.

Choi, H. C. and E. Sirakaya (2006) 'Sustainability Indicators for Managing Community Tourism', Tourism Management 27(6): 1274-89.

Creswell, J. W. (1998) Qualitative Inquiry and Research Design: Choosing Among Five Traditions. Thousand Oaks, CA: SAGE.

Cummins, R. A. (2005) 'Moving From the Quality of Life Concept to a Theory', Journal of Intellectual Disability Research 49(10): 699-706.

Dangi, T. B., and T. Jamal (2016) 'An integrated approach to "sustainable community-based tourism”, Sustainability 8(5): 475.

De Haan, F. J., B. C. Ferguson, R. C. Adamowicz, et al. (2013) 'The Needs of Society: A New Understanding of Transitions, Sustainability and Liveability', Technological Forecasting and Social Change 85: 121-32.

Decrop, A. (2004) 'Trustworthiness in Qualitative Tourism Research', pp. 156-69, in J. Phillimore and L. Goodson (eds) Qualitative Research in Tourism: Ontologies, Epistemologies and Methodologies. London: Routledge.

Dempsey, N., G. Bramley, S. Power, et al. (2011) 'The Social Dimension of Sustainable Development: Defining Urban Social Sustainability', Sustainable Development 19: 289-300.

Devine, F., T. Baum, N. Hearns, et al. (2007) 'Cultural Diversity in Hospitality Work: The Northern Ireland Experience', International Journal of Human Resource Management 18(2): 333-49. 
Diener, E. (2000) 'Subjective Well-Being: The Science of Happiness and a Proposal for a National Index', American Psychologist 55: 34-43.

Diener, E. (2009) The Science of Well-Being: The Collected Works of Ed Diener. Social Indicators Research Series 37.

Dissart, J. C. and S. C. Deller (2000) 'Quality of Life in the Planning Literature', Journal of Planning Literature 15(1): 135-61.

Dun, S. (2014) 'No Beer, No Way! Football Fan Identity Enactment Won't Mix With Muslim Beliefs in the Qatar 2022 World Cup', Journal of Policy Research in Tourism, Leisure and Events 6(2): 1-14.

Duncan, T., D. G. Scott and T. Baum (2013) 'The Mobilities of Hospitality Work: An Exploration of Issues and Debates' Annals of Tourism Research 41: 1-19.

Eizenberg, E. and Y. Jabareen (2017) 'Social Sustainability: A New Conceptual Framework', Sustainability 9(68): 1-16.

Ellington, L. (2009) Engaging Crystallization in Qualitative Research. New York, NY: SAGE.

Eslami, S., Z. Khalifah, A. Mardani, et al. (2019) 'Community Attachment, Tourism Impacts, Quality of Life and Residents' Support for Sustainable Tourism Development', Journal of Travel and Tourism Marketing 36(9): 1061-79.

Fainstein, S. (2010) The Just City. Ithaca, NY: Cornell University Press.

Green, F. and N. Stern (2014) An Innovative and Sustainable Growth Path for China: A Critical Decade. Policy paper. Centre for Climate Change Economics and Policy, Grantham Research Institute on Climate Change and the Environment.

Guo, Y., S. Kim and Y. Chen (2014) 'Shanghai Residents' Perceptions of Tourism Impacts and Quality of Life', Journal of China Tourism Research 10: 142-64.

GGRASIA (2014) 'Macau needs more migrant labour: Pansy Ho', GGRASIA. Available at: http:// www.ggrasia.com/macau-needs-more-migrant-labour-pansy-ho/ (accessed 25 June 2018).

Haas, B. K. (1999) 'A Multidisciplinary Concept Analysis of Quality of Life', Western Journal of Nursing Research 21: 728-42.

Hsu, C. H. C. and Z. Gu (2010) 'Riding on the Gaming Boom: How Can Hong Kong, Macau and Zhuhai Join Hands to Develop Tourism in the Region?' Asia Pacific Journal of Tourism Research 15(1): 55-77.

Institute for Tourism Studies (2015) Findings of the Annual Study of Macao's Tourism Carrying Capacity, 2013-2014. Macao SAR: IFT Press Release.

Jabareen, Y. R. (2006) 'Sustainable Urban Forms Their Typologies, Models, and Concepts', Journal of Planning Education \& Research 26: 38-52.

Janta, H., P. Lugosi, L. Brown, et al. (2012) 'Migrant Networks, Language Learning and Tourism Employment', Annals of Tourism Research 33(2): 431-9.

Joppe, M. (2012) 'Migrant Workers: Challenges and Opportunities in Addressing Tourism Labour Shortages', Tourism Management 33(3): 662-71.

Jordan, E. J., C. A. Vogt and R. P. Deshon (2015) 'A Stress and Coping Framework for Understanding Resident Responses to Tourism Development', Tourism Management 48: $500-12$.

Kimbu, A. N. and M. Z. Ngoasong (2016) 'Women as Vectors of Social Entrepreneurship', Annals of Tourism Research 60: 63-79.

Kim, K., M. Uysal and M. J. Sirgy (2013) 'How Does Tourism in a Community Impact the Quality of Life of Community Residents?', Tourism Management 36: 527-40.

Knollenberg, W., S. Brune, J. Harrison, et al. (2019) 'Strategies to Facilitate the Integration of Hispanic Migrants in a Tourism-Dependent Community', Journal of Policy Research in Tourism, Leisure and Events 13(1): 1-19. 
Labour Affairs Bureau (DSAL) (2021) About us. Available at: http://www.dsal.gov.mo/en/standard/index.html (accessed 7 June 2021).

Ladkin, A. (2011) 'Exploring Tourism Labor', Annals of Tourism Research 38(3): 1135-55.

Lai, H. K., P. Pinto and P. Pintassilgo (2018) 'Quality of Life and Emotional Solidarity in Residents' Attitudes toward Tourists: The Case of Macau', Journal of Travel Research 60(5): $1123-1139$.

Lau, C. and Y. Li (2019) 'Analyzing the Effects of an Urban Food Festival: A Place Theory Approach' Annals of Tourism Research 74: 43-55.

Li, X., Y. K. P. Wan and M. Uysal (2020) 'Is QOL a Better Predictor of Support for Festival Development? A Social-Cultural Perspective', Current Issues in Tourism 23(8): 990-1003.

Lin, Y. L., X. L. Zhang and S. Geertman (2015) 'Toward Smart Governance and Social Sustainability for Chinese Migrant Communities', Journal of Cleaner Production 107: 389-99.

Lin, J. H., J. Y. Wong and C. H. Ho (2013) 'Promoting Frontline Employees' Quality of Life: Leisure Benefit Systems and Work-to-Leisure Conflicts', Tourism Management 36: 178-87.

Liu, Y., F. Zhang, Y. Liu, et al. (2017). 'The effect of neighbourhood social ties on migrants' subjective wellbeing in Chinese cities', Habitat International 66: 86-94.

Loi, K. I. and W. G. Kim (2010) 'Casino Industry in Macao - Reinventing Las Vegas in Asia', Cornell Hospitality Quarterly 51(2): 268-83.

Matthew, P. V. and S. Sreejesh (2017) 'Impact of Responsible Tourism on Destination Sustainability and Quality of Life of Community in Tourism Destinations', Journal of Hospitality and Tourism Management 31: 83-9.

Matthews, B. and L. Ross (2010) Research Methods: A Practical Guide for the Social Sciences. London: Longman.

McWha, M., W. Frost and J. Laing (2018) 'Travel Writers and the Nature of Self: Essentialism, Transformation and (Online) Construction', Annals of Tourism Research 70: 14-24.

McCool, S. and S. Martin. (1994) 'Community Attachment and Attitudes Towards Tourism Development', Journal of Travel Research 32(3): 29-34.

McDowell, L., A. Batnitzky and S. Dyer (2009) 'Division, Segmentation, and Interpellation: The Embodied Labors of Migrant Workers in a Greater London Hotel', Economic Geography 83(1): 1-25.

MGTO (2017) Macao Tourism Industry Development Master Plan. Available at: https://masterplan.macaotourism.gov.mo/Comprehensive_Report_en.pdf (accessed 24 September 2018).

Moran, D. (2000) Introduction to Phenomenology. London: Routledge.

Morrison Institute for Public Policy (1997) What Matters in Greater Phoenix: 1997 Indicators of Our Quality of Life. Tempel, AZ: Arizona State University.

Moura, N. (2019) Migrant Workers Rights Advocates Dissatisfied With Lack of Response by Labour Department to Requests to Review Labour Practices. Macau Business. Available at: https:/www.macaubusiness.com/migrant-workers-rights-advocates-dissatisfied-withlack-of-response-by-labour-department-to-requests-to-review-labour-practices/ (accessed 25 March 2020).

Ngoasong, M. Z. and A. N. Kimbu (2016) 'Informal Microfinance Institutions and DevelopmentLed Tourism Entrepreneurship', Tourism Management 52: 430-39.

Nunkoo, R. and K. K. F. So (2016) 'Residents' Support for Tourism: Testing Alternative Structural Models', Journal of Travel Research 55(7): 847-61.

Nunkoo, R., S. L. J. Smith and H. Ramkissoon (2013) 'Residents' Attitudes to Tourism: A Longitudinal Study of 140 Articles From 1984 to 2010', Journal of Sustainable Tourism 21(1): 5-25. 
OECD (2014) Is migration good for the economy? https://www.oecd.org/migration/OECD\%20 Migration\%20Policy\%20Debates\%20Numero\%202.pdf (accessed 25 June 2018).

O’Regan, M. (2019) 'Post-Colonial Macau: Hope and Despair in a World Centre of Tourism and Leisure', Via. Tourism Review (16).

Perlaviciute, G. \& L. Steg (2018) 'Environment and Quality of Life', pp. 123-134, in L. Steg \& J. I. M. de Groot (eds) Environmental Psychology: An Introduction, Second Edition. BPS Wiley.

Polese, M. and R. Stren (eds) (2000) Social Sustainability of Cities: Diversity and the Management of Change. Toronto, ON: University of Toronto Press.

Purdue, R. R., P. T. Long and Y. S. Kang (1999) 'Boomtown Tourism and Resident Quality of Life: The Marketing of Gaming to Host Community Residents', Journal of Business Research 44(3): 165-77.

Rapley, M. (2003) Quality of Life Research: A Critical Introduction. London: SAGE.

Raphael, D., R. Renwick, L. Brown, et al. (1996) 'Quality of Life Indicators and Health: Current Status and Emerging Conceptions', Social Indicators Research 39: 65-88.

Robinson, R. N., A. Martins, D. Solnet, et al. (2018) 'Sustaining Precarity: Critically Examining Tourism and Employment', Journal of Sustainable Tourism 27(7): 1008-1025.

Ryan, G. W. and R. H. Bernard (2003) 'Techniques to Identify Themes', Field Methods 15(1): 85-109.

Saarinen, J. and C. M. Rogerson (2014) 'Tourism and the Millennium Development Goals: Perspectives Beyond 2015', Tourism Geographies 16(1): 23-30.

Schalock, R. L. (1997) Quality of Life, Volume II: Application to Persons with Disabilities. Washington, DC: American Association on Mental Retardation.

Schalock, R. L. (2000) 'Three Decades of Quality of Life', pp. 335-58, in M. L. Wehmeyer and J. R. Patton (eds) Mental Retardation in the 21st Century. Austin, TX: Pro-Ed.

Schalkwyk, G., E. Tran and K Chang. (2006) 'The Impact of Macao's Gaming Industry on Family Life: An Exploratory Study’, China Perspectives 64. http://chinaperspectives.revues.org/603 (accessed 10 September 2016).

Scheyvens, R. (2011) 'The Challenge of Sustainable Tourism Development in the Maldives: Understanding the Social and Political Dimensions of Sustainability', Asia Pacific Viewpoint 52(2): $148-64$.

Sheng, M. and C. Gu (2018) 'Economic Growth and Development in Macau (1999-2016): The Role of the Booming Gaming Industry', Cities 75: 72-80.

Sim, A. and V. Wee (2009) 'Undocumented Indonesian Workers in Macau: The Human Outcome of Colluding Interests', Critical Asian Studies 41(1): 165-88.

Skevington, S. M., M. Lotfy and K. A. O'Connell (2004) 'The World Health Organization's WHOQOL-BREF Quality of Life Assessment: Psychometric Properties and Results of the International Field Trial', A Report from the WHOQOL Group. Quality of Life Research 13(2): 299-310.

Spracklen, K., J. Long, \& J. Hylton (2015) 'Leisure opportunities and new migrant communities: Challenging the contribution of sport', Leisure Studies, 34(1): 114-129.

Stephenson, M. and J. Ali-Knight (2010) 'Dubai's Tourism Industry and its Societal Impact: Social Implications and Sustainable Challenges', Journal of Tourism and Cultural Change 8(4): 278-92.

Shi, W. (2017) 'Cultural Politics of Emotions in Households: Migrant Domestic Workers in Macau', Inter-Asia Cultural Studies 18(4): 464-81.

Souldard, J., N. G. McGehee and M. Stern (2019) 'Transformative Tourism Organizations and Glocalization', Annals of Tourism Research 76: 91-104. 
Terzi, F., H. D. Türkoğlu, F. Bölen, et al. (2015) 'Residents' Perception of Cultural Activities as Quality of Life in Istanbul', Social Indicators Research 122(1): 211-34.

Tong, K. K. and S. M. Yuen (2008) 'Quality of Life in Macao: Who is Happy and Satisfied?' Journal of Psychology in Chinese Society 9(1): 27-45.

Tracy, S. (2010) 'Qualitative Quality: Eight "Big Tent" Criteria for Excellent Qualitative Research', Qualitative Inquiry 16(10): 837-51.

Tuan, M. (1998) Forever Foreigners or Honorary Whites?: The Asian Ethnic Experience Today. New Brunswick, NJ: Rutgers University Press.

UNWTO (2015) Tourism and the SDGs. Available at: http://icr.unwto.org/content/tourism-andsdgs (accessed 23 September 2016).

Uysal, M., R. Perdue and M. J. Sirgy (2012) 'Prologue: Tourism and Quality-of-Life (QOL) Research: The Missing Links', pp. 1-5, in M. Uysal, R. Perdue and M. J. Sirgy (eds) Handbook of Tourism and Quality-of-Life Research. Dordrecht: Springer.

Uysal, M., M. J. Sirgy, E. Woo, et al. (2016) 'Quality of Life (QOL) and Well-Being Research in Tourism', Tourism Management 53: 244-61.

Verdugo, M. A., R. L. Schalock, K. D. Keith, et al. (2005) 'Quality of Life and its Measurement: Important Principles and Guidelines', Journal of Intellectual Disability Research 49(10): $707-17$.

Vong, T. N. (2005) 'Leisure Satisfaction and Quality of Life in Macao, China', Leisure Studies 24(2): 195-207.

Wan, Y. K. P. and S. H. J. Chan (2013) 'Factors that Affect the Levels of Tourists' Satisfaction and Loyalty Towards Food Festivals: A Case Study of Macau', International Journal of Tourism Research 15(3): 226-40.

Wan, Y. K. P. and X. Li (2013) 'Sustainability of Tourism Development in Macao, China', International Journal of Tourism Research 15(1): 52-65.

WHOQOL Group (1994) 'Development of the WHOQOL: Rationale and Current Status', International Journal of Mental Health 24: 24-56.

Williams, A. M. and C. M. Hall (2000) 'Tourism and Migration: New Relationships Between Production and Consumption', Tourism Geographies 2(1): 5-27.

Woo, E., H. Kim and M. Uysal (2015) 'Life Satisfaction and Support for Tourism Development', Annals of Tourism Research 50: 84-97.

Woods, P. (2006) Successful Writing for Qualitative Researchers. 2nd edn. Oxon: Routledge.

Wyman, O. (2020). To Recover \& Beyond: The Future Of Travel \& Tourism In The Wake Of Covid-19. WTTC.

Yeoh, B. (2006) 'Bifurcated Labour: The Unequal Incorporation of Transmigrants in Singapore', Tijdschrift Voor Economische En Sociale Geografie 97(1): 26-37.

Yew, L. T. (2007) 'Job Satisfaction and Affective Commitment: A Study of Employees in the Tourism Industry in Sarawak, Malaysia', World Review of Entrepreneurship 4(1): 85-101.

Zhang, H. Q., D. X. F. Fan, T. S. M. Tse, et al. (2017) 'Creating a Scale for Assessing Socially Sustainable Tourism', Journal of Sustainable Tourism 25(1): 61-78.

Zhou, Q. B., J. Zhang, H. Zhang, et al. (2015) ‘A Structural Model of Host Authenticity', Annals of Tourism Research 55: 28-45.

\section{Author biographies}

Jaeyeon Choe is a Visiting Professor at the School of Hospitality and Tourism at Hue University, Vietnam. Her primary research areas include Migrant and Marginalised Community Well-being, Social Sustainability of Destinations, and Wellness/Spiritual Tourism. 
Michael O' Regan researches tourist, urban, historic, future, slow, alternative and cultural mobilities and Chinese Outbound Tourism.

Albert Kimbu researches tourism stakeholder networks and gendered entrepreneurial pathways for inclusive development.

Niels Frederik Lund is a lecturer in Media, Communication and Business at Erasmus University Rotterdam. He holds a PhD in Tourism Management from Surrey University. His research interests are storytelling, branding, social media, and visitor attractions. He works with destination development and is an advisor to Stevns UNESCO world heritage.

Adele Ladkin researches tourism employment, work-life balance, labour mobility and migration. 